\title{
ASSESSMENT OF LONG DURATION PIGEON PEA (Cajanuscajan) VARIETIES WITHSTAND DROUGHT AND WILT DISEASE IN RAINFED REGION OF NORTH EASTERN ZONE OF TAMIL NADU
}

\author{
P. Veeramani ${ }^{1}$ and V. Sendhilvel ${ }^{2}$ \\ ${ }^{1}$ ICAR-KrishiVigyan Kendra, Tamil Nadu Agricultural University, Vellore-632104, Tamil Nadu. \\ ${ }^{2}$ Department of Plant Pathology, Tamil Nadu Agricultural University, Coimbatore-641003, Tamil Nadu
}

\begin{abstract}
A study was conducted for evaluation of different long duration and high yielding pigeonpea varieties in rainfed region of North Eastern Zone of Tamil Nadu to assess its drought and wilt disease tolerance. The field trials were conducted at Vellore district, Tamil Nadu during Kharif season 2017-18using improved varieties along with ruling verities as comparative check. The experimental plot was laid out in Randomized Block Design (RBD) and replicated in five times with the improved varieties of LRG 41, LRG 52 and CO-8 that are conferred for rainfed condition along withruling pigeonpea variety CO-7 as Farmers practices. During the study, the recommended dose of fertilizer (RDF) was applied as per crop production guide. The growth and yield attributes viz.,plant height $(\mathrm{cm})$, number of primary and secondary branches per plant, number of pods per plant, seed yield $(\mathrm{kg} / \mathrm{ha})$, Stover yield $(\mathrm{kg} / \mathrm{ha})$ were recorded. The wilt disease caused by Fusarium udum Butler which is predominant yield limiting disease was also recorded. The results on field level performance the genotypes revealed that the pigeonpea CO 8 was recorded maximum plant height (184.2 cm), higher number of primary branches per plant (16.7), secondary branches per plant (29.5), number of pods per plant (279.8), minimum incidence (7.0 \%) wilt disease with higher yield of $1290 \mathrm{~kg} / \mathrm{ha}$ was gained. Based on the on farm trial results, it could be concluded that the long duration pigeonpea variety CO 8 was found to be better option for achieving higher productivity and profitability under the rainfed region of North Eastern Zone of Tamil Nadu.
\end{abstract}

Keywords: Pigeonpea, Rainfed, Variety, Wilt.

\section{INTRODUCTION}

Pigeonpea (Cajanus cajan) also known as arhar or tur or redgram is one of the most essential grain legumes in India with $90 \%$ of global production confined within the country. It is largely cultivated and consumed in developing countries and this crop is widely grown in India. Pigeon peais the second most important pulse crop in India after chickpea. Pigeonpea occupies an area of around 3.47 million hectares in India with a production of 2.77 million tonnes which accounts for a productivity of 799 $\mathrm{Kg} / \mathrm{ha}$. In Tamil Nadu the area under pigeonpea is about 1.40 lakh hectares with a production of 1.20 lakh tons and the productivity is $864 \mathrm{Kg} / \mathrm{ha}$, which is higher than the average national productivity, but lower than the productivity level of Uttar Pradesh (1134 Kg/ha), Haryana (1145 Kg/ha), Bihar (999 Kg/ha), Gujarat (952 Kg/ha) and Punjab (880 Kg/ha).

It also plays an important part in sustainable agriculture by enriching the soil through biological nitrogen fixation along with deep root system of this crop which makes it more suitable for its cultivation under rainfed conditions. Pigeonpea crop generally enhances soil fertility through leaf litter and biological nitrogen fixation (Udhayaet al., 2015).The crophas ability to fix 41 to $250 \mathrm{~kg}$ ha of nitrogen throughsymbiotic association between the root nodules and aspecies of bacteria, Rhizobia (Kwame, 2003).The

*Corresponding author: veera.agri@yahoo.com 
observed low yield is as a result of use of poor quality long duration varieties, pests and diseases attack, poor crop management and low soil fertility. Traditional varieties of pigeonpea need about 6 to 9 months to mature, while the improved varieties developed can be harvested in 3-4 months. Both long duration (180 days) and medium duration (130-140 days) genotypes are grown in Tamil Nadu under various cropping systems. Because of shorter growing period and low moisture in soil as well as high atmospheric temperature, the productivity is low. These abiotic stresses are further aggravated by biotic stresses like pod borers, wilt and sterility mosaic (Gurdip Singh and Livinder Khar Bhavan, 1998). In Vellore District, mostly farmers using available long duration varieties with yield of $450 \mathrm{~kg} /$ ha due to non-adoption of improved varieties and technologies. Wilt incidence also occurs higher in the farmers practice due to continuous cultivation of same variety. Among the diseases, wilt and sterility mosaic disease are the major constraint to pigeonpea production worldwide (Kannaiyan et al., 1984). Recent surveys have indicated that major losses in the pigeonpea are due to wilts and losses varying from 0.2 to 100 per cent have been estimated in India (Gade, 2002). The wilt incidence of pigeon pea has been reported from 30 to $60 \%$ at flowering and crop maturity stages (Kannaiyan and Nene, 1981), however it can also cause yield losses up to $100 \%$ in susceptible cultivars (Kannaiyan et al., 1984; Reddy et al., 1990; Okiror, 1999; Dhar et al., 2005). In these above limitations, present study was conducted with an objective to identify the suitable long duration and high yielding pigeonpea varieties under rain fed condition to confer wilt resistance.

\section{MATERIALS AND METHODS}

On farm trails (OFTs) was conducted in the various farmers field of Vellore district, Tamil Nadu during Kharif season 2017 - 2018. The soil type of the trial plot was red sandy loam with low organic carbon (0.4\%), available nitrogen $227(\mathrm{~kg} / \mathrm{ha})$, available phosphors $8.4(\mathrm{~kg} / \mathrm{ha})$ and available potassium 172 (kg/ha). The experimental site received 842 $\mathrm{mm}$ of the rainfall and $410 \mathrm{~mm}$ of rainfall received during the cropping period. The experimental plot was laid out in Randomized Block Design (RBD) and replicated in five times with improved varieties such as LRG 41, LRG 52 and CO-8.The plant materials were obtained from the Department of pulses, TNAU, Coimbatore. The existing pigeonpea variety CO-7 used as farmers practices. The observations on growth and yield parameters were recorded in randomly selected plants. The seeds were treated with Trichoderma viride @ 4 g/ kg of seeds. Appropriate need based plant protection measures were taken up to control the pest and diseases following the recommended packages of practices as per the crop production guide (Anonymous, 2012). Each trial plot was conducted in 0.4 ha. Data were recorded on Plant height (cm), Number of primary branches/plant, Number of secondary branches/plant, Number of pods/plant, Seed yield (kg/ha), Stover yield(kg/ha) and harvest index. The periodical observations on growth and yield contributing characters of pigeonpea and wilt incidence percentage, economics of all the varieties were recorded.

\section{Data collection on wilt disease incidence:}

Data on wilt incidence (\%) was recorded at seedling, flowering and maturity stage of the crop at each location. Cumulative incidence of all the three stages was calculated using the following formula:

\section{Percentage of disease incidence}

$=$ No. of infected plants/Total no. of plants $\times 100$

Depending upon the range of wilt incidence, the test entries were categorized as resistant ( $<10.0 \%$ incidence), moderately resistant (10.1-20.0\% incidence), susceptible (20.1-40.0\% incidence), and highly susceptible (>40\% incidence). Prior to analysis, the percentage data was arcsine transformed to make residual normal (Gomez and Gomez, 1984).

\section{RESULT AND DISCUSSION Effect of Pigeonpea varieties on growth parameters}

Growth and development in plants are importance of excellent direction of several developments operating at different growth stages of plant. The growth of pigeonpea influenced by various long duration varieties has been elucidated through the positive response on plant height. Among the different pigeonpea varieties CO-8 recorded significantly higher plant height (184.2), followed by LRG 52 (172.5) and lowest plant height was recorded in CO-7 (155.4). Primary branches per plant were significantly more in CO-8 (16.7) followed by LRG 52 (14.3). Secondary branches also recorded similar to primary branches in different pigeonpea varieties. This may be attributed due to the genetic variation of the different varieties. The reason may be attributed to their genetic variability, varietal difference and environmental adaptability. Similar results were also reported by Samant (2014).

\section{Yield}

Among the different pigeonpea varieties evaluated significantly the highest seed yield of $1290 \mathrm{~kg} / \mathrm{ha}$ were recorded in CO-8 variety followed by the LRG 52 variety $1128 \mathrm{~kg} / \mathrm{ha}$. This influence due to adoption of improved agricultural practices with long duration variety resulted more number of branches and pods per plant. The lowest yield of $842 \mathrm{~kg} /$ ha were recorded in farmer practices CO-7. Increase in seed yield was due to better synchronization of flowering resulted in higher number of pod set. The improvement in yield and yield attributing characters of pigeonpea by the application of growth retardants might be 
owing to its positive effect on growth which in turn resulted in the development of higher yield attributing characters and ultimately increased seed yield (Kiran Kumar et al., 2005).Khush (1996) noted that when same set of genotypes demonstrate differential flowering pattern due to environmental factors the earlier to flower usually takes longer time to fill pods and consequently produced higher grain yield.

Table 1: .Growth and yield parameters in different long duration pigeonpea varieties.

\begin{tabular}{|l|c|c|c|c|}
\hline $\begin{array}{l}\text { Varieties / } \\
\text { Parameters }\end{array}$ & Plant height $\mathbf{( c m )}$ & $\begin{array}{c}\text { No. of primary } \\
\text { branches/ plant }\end{array}$ & $\begin{array}{c}\text { No. of secondary } \\
\text { branches/plant }\end{array}$ & No. of Pods/ plant \\
\hline Farmer practices & & & & 229.4 \\
\hline CO-7 & 155.4 & 11.2 & 20.6 & 241.7 \\
\hline LRG 41 & 166.8 & 12.6 & 22.1 & 261.0 \\
\hline LRG 52 & 172.5 & 14.3 & 25.4 & 279.8 \\
\hline CO-8 & 184.2 & 16.7 & 29.5 & 9.4 \\
\hline SEd & 6.8 & 1.27 & 2.4 & 21.0 \\
\hline CD $(P=0.05)$ & 15.1 & 2.79 & 4.9 & \\
\hline
\end{tabular}

\section{Wilt incidence}

The sensitivity of the genotypes against wilt disease was observed in the field study and results are tabulated in Table2. The long duration variety Pigeon pea Co8 was conferred as resistant to wilt disease with the incidence of $7.1 \%$ at maturity stage of the crop followed by LRG52 which scored $18.1 \%$ wilt incidence. The LRG 41 and Co7 were highly susceptible and there is no significant variation on disease reaction. The seed ling stage of the crop of all the genotypes were shown less incidence, Our study focused on the effect of the genetic background (genotype) and the environments impact on the F. udumpigeonpea interaction under rainfed condition. Similar results were found by other studies; Shrama et al., (2016) stated that the lowest wilt incidence and high stability of resistance under diverse climatic conditions are essential for the establishment of a crop and sustainable production. Demisew (2010) reported that genetically improved varieties have better performance and higher degree of genetic potential for disease resistance than old varieties. Jimenes-Diaz et al., (1993) reported that the cultivation of resistant cultivars is the most effective and economical way for controlling the wilt disease. The pigeon pea variety Co8 was shown resistance against new races of isolates; they may have multiple genes of resistance to this descriptive disease.

Table 2: Wilt incidence (\%) of long duration pigeonpea varieties in rainfed condition.

\begin{tabular}{|l|c|c|c|c|}
\hline $\begin{array}{l}\text { Varieties / } \\
\text { Parameters }\end{array}$ & Seedling stage & Flowering stage & Maturity stage & $\begin{array}{c}\text { Resistant } \\
\text { category }\end{array}$ \\
\hline Farmer practices & 4.6 & 21.5 & 49.9 & Highly susceptible \\
\hline CO-7 & 5.1 & 18.6 & 46.3 & Highly susceptible \\
\hline LRG 41 & 2.1 & 12.4 & 18.1 & Moderately Resistant \\
\hline LRG 52 & 1.6 & 4.5 & 7.1 & Resistant \\
\hline CO-8 & 0.08 & 1.31 & 3.80 & \\
\hline SEd & 0.21 & 2.72 & 8.13 & \\
\hline CD $(\mathrm{P}=0.05)$ & & & & \\
\hline
\end{tabular}

\section{Economics}

Higher net income and minimum cost of cultivation are desirable parameter for getting maximum profitable in any cropping programme. Hence, economics of the treatment were worked out and tabulated in Table3. The results revealed that the data obtained from pigeonpea variety CO8 recorded the highest yield $(1290 \mathrm{~kg} / \mathrm{ha})$ with the highest economic return (Rs. 58,050). The maximum benefit cost ratio (2.9)was recorded in the variety CO-8 followed by 2.6 from LRG 52. The pigeon pea variety namely LRG 52 gave 
the second highest yield (1128 kg/ha) with net return (Rs. $50,760)$. The existing variety Co7 recorded minimum grain yield of $842 \mathrm{~kg} / \mathrm{ha}$, net return Rs. 37,890 and benefit cost ratio 1.90 .

Table 3: Effect of yield parameters and economics in different long duration pigeonpea varieties.

\begin{tabular}{|l|c|c|c|c|c|}
\hline $\begin{array}{l}\text { Varieties / } \\
\text { Parameters }\end{array}$ & $\begin{array}{c}\text { Seed yield } \\
\text { (kg/ha) }\end{array}$ & $\begin{array}{c}\text { Stover yield } \\
\text { (kg/ha) }\end{array}$ & Harvest Index & Net return (Rs.) & $\begin{array}{c}\text { Benefit } \\
\text { cost ratio }\end{array}$ \\
\hline Farmer practices & & & & & \\
\hline CO-7 & 842 & 3037 & 0.28 & 37890 & 1.9 \\
\hline LRG 41 & 912 & 3409 & 0.27 & 41040 & 2.1 \\
\hline LRG 52 & 1128 & 3740 & 0.30 & 50760 & 2.6 \\
\hline CO-8 & 1290 & 4216 & 0.31 & 58050 & 2.9 \\
\hline SEd & 52.3 & 98.0 & 0.01 & - & - \\
\hline CD $(P=0.05)$ & 120.6 & 208.1 & 0.04 & - & - \\
\hline
\end{tabular}

\section{CONCLUSION}

Based on the results, it was concluded that long duration pigeopea variety CO-8 recorded significantly higher growth, yield parameters and economics compared with other pigeopea varieties. Higher return and benefit cost ratio recorded in $\mathrm{CO}-8$ and the farmers were satisfied with CO-8 due to its escaping from drought and flower drops capacity. Therefore CO-8 pigeonpea variety would be identified as a better variety for North eastern zone of Tamil Nadu.

\section{LITERATURE CITED}

1. Anonymous. (2012). Crop production guide, Tamil Nadu Agricultural University, Coimbatore, 2012.

2. Demissew T. 2010. Genetic gain in grain yield and associated traits of earlyand medium maturing varieties of soybean [Glycine max (L.) Merrill]. An M. Sc.Thesis Presented to the School of Graduate Studies of Haramaya University.

3. Dhar V, Reddy M V, Chaudhary R G. (2005). Major diseases of pigeonpea and their management, in Advances in Pigeonpea Research, eds Ali M., Kumar S. (Kanpur: Indian Institute of Pulses Research), 229-261.

4. Gade R M (2002). Integrated disease management of pigeonpea wilt. Ph.D.Thesis, Marathwada Agricultural University, Parbhani, M.S. (India).

5. Gomez K. A. and Gomez A. A. (1984). Statistical Procedure for Agricultural Research. 2nd Edn., New York, NY: Wiley.

6. Gurdip Singh and Livinder Khar Bhavan. (1998). Diseases of Mungbean and Urdbean and their management. In: IPM system in Agriculture vol.4.
Pulses Aditya Books Private Limited, New Delhi. pp 311-371.

7. Jimenez-Diaz R M, Hervas AA and Trapero- Casas J C (1993). Pathogenic variability and host resistance in Fusarium oxysporumf. sp. ciceri/Cicerarietinum pathosystem. Hodowla Rosin, Aklima tyzacja Nasiennic 37: 87-94.

8. Kannaiyan J., Nene Y. L., Reddy M. V., Ryan J. G. and Raju T. N. (1984). Prevalence of pigeonpea diseases and associated crop losses in Asia, Africa and America. Trop. Pest Manage. 30, 62-71.

9. Khush G. S. (1996). Strategies for increasing crop productivity. Proceedings of 2nd International Crop Science Congress.19-43 .V. L. Chpra, R. B. Singh and Anupamvarma editors Oxford x IBH Publishing Co. PVT.Ltd. New Delhi and Calcultta.

10. Krian Kumar K. A., Patil B. C. and Chetti M. B. 2005. Effect of plant bio regulators on physiological components by yield in hybrid cotton. Indian Journal of Plant Physiology10: 187-90.

11. Kwame F. P. (2003). Correlation and Path Coefficient analysis of yield and yield components in pigeonpea. Pakistan J. Bio. Sci., 6(19): 1689-1694.

12. Samant T. K. (2014). Evaluation of growth and yield parameters of greengram (Vigna radiata L).Agric. Update., 9:427-30.

13. Sharma M., Ghosh R., Telangre R., Rathore A., Saifulla M., Mahalinga D. M., Saxena D. R. and Jain Y. K. (2016). Environmental Influences on Pigeonpea-Fusariumudum Interactions and Stability of Genotypes to Fusarium Wilt. Frontiers in plant science, 7, 253. 
14. Udhaya N. D., Vimalendren L., Letha K. R., Sangamithra S and Kalaiyarasan V. (2015). A Review on biological advantage of Pigeonpea intercropping influenced by different cropping geometries. Int J Agric Sci Res5: 103-12.

15. Kannaiyan J. and Nene Y. L. (1981). Influence of wilt at different growth stages on yield loss in Pigeonpea. Trop. Pest Manage. 27, 141.
16. Reddy M. V., Nene Y. L., Kannaiyan J., Raju T. N., Saka. V. W., Daudi A. T. (1990). Pigeonpea lines resistant to wilt in Kenya and Malawi. Int. Pigeonpea Newsletter 12, 25-26.

17. Okiror M. A. (1999). Evaluation of pigeonpea (Cajanuscajan) germplasm for resistance to Fusarium wilt. Indian J. Agric. Sci.69. 